\title{
Research on the Construction and Development of Teaching and Research Offices in Private Colleges and Universities*
}

\author{
Youping Zhao \\ Hubei Business College \\ Wuhan, China 430079
}

\begin{abstract}
Since the 1950s and 1960s, China's colleges and universities have generally adopted the teaching management mode of the former Soviet Union and Eastern European countries to set up a teaching and research office, which has a history of more than 60 years. In order to adapt to the development of China's colleges and universities, the grassroots organization of the teaching and research office should be included in the school's governance system to clarify the power, responsibility and interest of the teaching and research office, and to establish united and progressive teaching and research office culture, so as to lay a foundation for the development of private colleges and universities.
\end{abstract}

Keywords-teaching and research office positioning; teaching and research office responsibilities; teaching and research office culture

\section{INTRODUCTION}

Since the 1950s and 1960s, China's colleges and universities have generally adopted the teaching management mode of the former Soviet Union and Eastern European countries to set up a teaching and research office, which has a history of more than 60 years. In 1961, "Sixty Articles on Higher Education" defined the teaching and research office as "teaching organization". In order to adapt to the development of higher education in China, the functions of the teaching and research office have been expanded a lot in recent decades. However, there are still many problems, especially the construction of teaching and research offices in private colleges and universities, with complex affairs, limited resources and prominent contradictions.

\section{DEVELOPMENT STATUS AND EXISTING PROBLEMS OF TEACHING AND RESEARCH OFFICE IN PRIVATE COLLEGES AND UNIVERSITIES}

\section{A. The Setting of the Teaching and Research Office Is Unreasonable}

Most of the teaching and research offices of private colleges and universities are set up according to disciplines or majors. One department has a teaching and research office,

\footnotetext{
*Fund: Teaching and Research Project of Hubei Business College.
}

and one major has a college (department). With the continuous deepening of education reform, disciplines and majors have been constantly adjusted, such as the new business, new arts, new engineering and new art, etc. advocated here and now. There are also some courses or new majors that reflect interdisciplinary characteristics. For example, big data accounting, etc. At this point, the establishment of the traditional teaching and research office leads to a single function, which can't play its role in the interdisciplinary professional construction, can only communicate across different teaching and research offices and even college (department), involving the issue of new major's focal point college (department). Such communication with low efficiency and high coordination cost is not conducive to the construction of new disciplines and the cultivation of compound talents.

\section{B. The Responsibility, Power, and Interest of Teaching and Research Office Is Not Clear}

As the grassroots organization of the college (department), the teaching and research office often undertakes various tasks including teaching organization and management, formulation and revision of talent training programs, teaching reform and research, curriculum examination mode reform, scientific research management and teacher team construction. However, as a local application-oriented university, private colleges and universities have a short history of running schools, and the system construction is not sound enough. As a result, the responsibilities of the teaching and research offices are not clear, and the rights and responsibilities are seriously unequal, which affects the normal function of the teaching and research section.

\section{There Are Too Many Administrative Affairs in the Teaching and Research Office, and the Teaching and Research Time Is Limited}

As a grass-roots teaching and research organization, the teaching and research office should be de-administrated since it is not an administrative organ of the school, so as to avoid too much administrative work for the teaching and research office, especially the director of the teaching and research office. However, the fact is that the division of work 
among the director of teaching and research office, teaching secretary and office director of private colleges and universities is not clear and reasonable. Some work that should have been undertaken by the teaching secretary falls on the director of the teaching and research office, for example, whether the format of examination paper is reasonable, the recruitment of external teachers and the management of external teachers, all these have become the duties of the director of the teaching and research office. The routine work occupies most of the energy of the director of the teaching and research office. On the contrary, the teaching and research activities that should be carried out normally by the teaching and research office cannot be carried out with quality and quantity, which greatly affects the effectiveness of the teaching and research section.

In addition to above-mentioned administrative affairs needed to be handled by the director of the teaching and research office, the non-regular staff meetings, regular meetings of the college (department), regular political study, etc., also greatly squeezed the time for the teaching and research office to carry out activities. Over time, the routine work of the director of the teaching and research office replace the original weekly teaching and research activities, while the teaching and research activities in the true sense only be a mere formality.

\section{The Relationship Between the Teaching and Research Office and the Teaching Team Is Unclear}

The "Opinions of the Ministry of Finance and Ministry of Education on the implementation of undergraduate teaching quality and teaching reform projects in higher education institutions" (Jiao Gao [2007] No. 1) mentions that in order to improve the quality and teaching ability of teachers in higher education institutions in China, and to ensure the continuous improvement of the quality of higher education, a teaching team construction project was established in the undergraduate teaching quality and teaching reform project in colleges and universities. On July 1, 2011, the Ministry of Education and the Ministry of Finance of the People's Republic of China jointly issued the implementation opinions of the "Undergraduate Teaching Project" and officially launched the "Undergraduate Teaching Quality and Teaching Reform Project". The "Undergraduate Teaching Project" puts forward the guidance for strengthening the construction of teaching teams in colleges and universities, and the teaching team has become one of the key construction projects for implementing "quality engineering".

In this context, many colleges and universities have set up a teaching team. What is the relationship between the teaching team and the teaching and research office of private universities? At present, there are two situations: some teaching and research offices are small in number, and the teaching team and the teaching and research office are completely coincident. The teaching research and teaching reform projects are carried out by the teaching team, while the daily teaching and management work is carried out by the teaching and research office. Such method leads to a problem: the director of the teaching and research office often serves as the head of the teaching team, too. Against such circumstances, it is difficult for the teaching team to generate new vitality, and it is difficult to achieve the goal of the "undergraduate teaching project". Some teaching and research offices are large in number. Only a small member of the teaching and research office serve as a member of the teaching team. The head of the teaching team may be the director of the teaching and research office, or may not be the director of the teaching and research office. Such noncoincident state is conducive to the formation of a more reasonable research direction. The teaching team with a relatively reasonable structure of professional title and academic degree is more conducive to bursting into vitality and actively carrying out teaching research and teaching reform.

\section{ThE POSITIONING AND FUNCTIONS OF GRASSROOTS TEACHING UNITS IN FOREIGN COUNTRIES}

The positioning and functions of the grassroots teaching units are institutional arrangements made under the guidance of certain values. The following will introduce the positioning and functions of teaching grass-roots units in the former Soviet union, Germany, the United States and Japan respectively, and provide certain reference basis for the construction of teaching and research offices in Chinese universities through comparison.

\section{A. The Former Soviet Union Positioned the Teaching and Research Office as a "Teaching-oriented" Personnel Training Unit}

Colleges and universities in the Soviet Union set up departments according to disciplines and majors, arrange corresponding majors according to departments, set up teaching and research offices according to courses, and then arrange corresponding courses according to teaching and research offices. Such "school-department-teaching and research office" mode removes the scientific research attribute of grass-roots teaching organization emphasized by western universities, while emphasizes its teaching function. Teachers focus on teaching, which is conducive to the cultivation of professional talents.

\section{B. German Institutes Highlight Teaching Democracy and Academic Freedom}

German colleges and universities implement the organization model of "university-college-institute". As a grassroots teaching unit, the institute is dominated by the head of the institute - leading professor, which has full freedom of teaching and research, highly integrated teaching and scientific research, and pays attention to the individualized development of teachers.

\section{The Grassroots of Teaching and Research in the United States Belong to Different Organizations}

American colleges and universities regard departments as basic teaching units, and special scientific research units undertake scientific research. As a community organization, the department inherits the "teaching democracy" and "academic freedom" advocated by Germany. Teachers can 
independently and freely choose and arrange teaching contents according to their own research direction and values.

\section{The Teaching and Research Office in Japan Is a Basic Unit That Combines Teaching and Scientific Research}

The teaching and research offices of Japanese universities are generally set up according to the professional research direction. As a grass-roots teaching and research organization, each teaching and research office is generally composed of a professor and an associate professor and several assistants, secretaries, technicians, researchers and students. The main person in charge of the teaching and research office is responsible for the teaching and research activities of the teaching and research section, as well as the administrative management of the school.

The teaching and research offices of Japanese universities usually hold regular seminars, in which each member is required to report recent research progress, achievements or difficulties, and then have a free discussion. In addition to internal discussions in teaching and research offices, colleges and universities also organize interdisciplinary and inter-professional theme seminars and academic exchanges within their own schools, provinces and even nationwide, so as to enhance exchanges and promote the development of interdisciplinary, marginal and emerging disciplines.

\section{SUGGESTIONS ON THE CONSTRUCTION OF TEACHING AND RESEARCH OFFICE IN PRIVATE COLLEGES AND UNIVERSITIES IN CHINA}

Based on the needs of China's higher education development and the typical characteristics of private colleges and universities, this paper puts forward some Suggestions on building the teaching and research office system of private colleges and universities in China.

\section{A. Finding the Positioning of the Teaching and Research Offices of Private Colleges and Universities}

The establishment of teaching and research offices in colleges and universities in China originated from the former Soviet Union, but the pure teaching-oriented personnel training units can no longer meet the needs of social development. China's current value assessment standards focus on scientific research rather than teaching. This is because it is difficult to have a unified standard for evaluating the level of teaching, while the level of scientific research can be evaluated - the number of research projects, papers, patent and so on. Such evaluation standard is applicable not only in public schools, but also in private colleges and universities. However, in view of the short history of running schools and relatively weak scientific research strength of private colleges and universities, the orientation of the teaching and research office should give priority to teaching and research and give consideration to scientific research, which is in line with the mainstream value evaluation system.

\section{B. Reviewing the Establishment Standards of the Teaching and Research Office}

It is reasonable to use disciplines and majors as the setting standards for teaching and research office. However when students majoring in such major are large in number, the research directions of the members in the same teaching and research office may be quite different. When there are many interdisciplinary subjects among different majors in the same college, there may be overlapping and duplication of research directions among members of different teaching and research offices. At this point, the original standards of the teaching and research office should be re-examined. If necessary, teams should be organized according to the research direction and members rescheduled according to their research directions, so as to ensure that the members of the teaching and research office can form teams to do scientific research and play a role in giving consideration to scientific research.

\section{Reshaping the Progressive Culture of Teaching and Research Office}

The current situation of individual teachers in private colleges and universities fighting alone in scientific research is not conducive to the effective integration of resources, nor is it conducive to the construction of cohesive culture in teaching and research office. To change this situation, it's a must to guide and promote the exchange between teachers on the system construction. The quantifiable assessment forms, such as mentoring, curriculum construction, centralized lesson preparation, lesson grinding, centralized discussion and joint application of subjects, can be used to guide teachers' values and gradually form a teaching and research office culture of solidarity, cooperation and initiative.

\section{Building a Learning-oriented Teaching and Research Office}

In the era of knowledge economy and information explosion, it is impossible for individual teachers to master all the professional knowledge and cutting-edge achievements in a certain field. Therefore, professional development, exploration and innovation need to rely on collective wisdom. The construction of a learning-oriented teaching and research office requires not only the members of the teaching and research office to exchange research experiences on a regular basis (at least once a month), but also to break the barriers between the teaching and research offices and even between colleges (departments), to conduct interdisciplinary exchanges on a regular or irregular basis, so as to exchange ideas and insights, to contribute collective wisdom to the development of new business, new arts, new engineering and new arts.

The construction of learning-oriented teaching and research office should not only carry out regular seminars in form, but also guarantee and supervise in system to ensure that seminars will not become mere forms. The aggressive teaching and research office culture is beneficial to the construction of learning-oriented teaching and research office. 


\section{E. Clarifying the Responsibilities, Powers, and Interests of the Teaching and Research Office}

The emphasis on teaching and research makes the daily work of the teaching and research office include not only the daily teaching organization and management, but also the teaching and research and research work in an orderly manner. First of all, the post of secretary of the teaching and research office should be added. The secretary should carry out daily teaching organization and management under the guidance of the director of the teaching and research office, and do a good job of data accumulation. Secondly, the director should identify his or her own position, not only the responsible person of daily teaching management, but also the organizer of teaching research and scientific research activities.

As the head of the teaching and research office, the director of the teaching and research office is also the spiritual leader of the teaching and research office. In addition to good professionalism and ethical standards, he or she should also have strong teaching and research capabilities, capable of formulating the medium and longterm development of the teaching and research office with the cooperation of office members, planning and organizing the teaching and research team within the teaching and research office, communicating actively with other teaching and research offices or colleges (departments) when cooperation is needed, and promoting cross-disciplinary interdisciplinary (department) discussion, laying the foundation for interdisciplinary development of certain professions.

\section{F. Institutional Guarantee}

The construction of teaching and research office is inseparable from institutional guarantee.

1) Necessary material security: The relevant departments of private colleges and universities shall coordinate and cooperate with each other, configure necessary office conditions for the teaching and research office, and equip the relevant hardware facilities such as printers, computers and projectors according to the professional requirements. The school shall purchase the professional materials, books, databases and other materials necessary for teaching and research office. The accumulation of scientific research data is also an essential link. On the basis of school material security, the secretary of the teaching and research office should do a good job in data collection and sorting.

2) The security of the organization: As mentioned above, the teaching and research office should be equipped with secretary to undertake the daily teaching management and other administrative affairs of the teaching and research office, so that the director can be liberated from trivial matters, and lead office members to carry out more valuable teaching and research activities.

3) The guarantee of talents: Private colleges and universities have a low starting point, and there are some teachers with rich teaching experience, but relatively weak scientific research ability. In the follow-up development of private colleges and universities, it is necessary to improve the teaching and research ability of grassroots organizations, and recruit some doctors and excellent masters with stronger scientific research ability, forming the pattern that the senior teachers help fresh teachers in teaching, while the fresh teachers help senior teachers in scientific research, and building a talent structure with complementary advantages.

4) The evaluation and appraisal system: Private colleges and universities should take the evaluation of the teaching and research office and the teaching and research team below the teaching and research office as an important task, and replace the evaluation of individual teachers performance with the evaluation of the teaching and research office. In this way, teachers can be guided to take the teaching and research office or the teaching and research team as the unit. The assessment of teaching and research office should include process assessment and result assessment. Such an assessment and assessment system is conducive to promoting the formation of teaching and research office culture and cohesion of team spirit. Of course, corresponding measures should be taken to avoid free-riding behavior of individual teachers in the teaching and research office.

\section{CONCLUSION}

Only when the foundation is firm can the building be high. The construction and management of the teaching and research office will affect the daily teaching, personnel training and scientific research level of colleges and universities. The private colleges and universities can learn from the experience of the developed countries in the construction of the teaching and research office. On the basis of maintaining the administrative system of the original teaching and research office, the teaching and research office will be incorporated into the internal governance system of private colleges and universities, and the power is transferred downward to build a new teaching and research office culture and establish a teaching and research office system that makes teachers' individual development and teaching and research office platform construction complement each other, laying a foundation for the development of private colleges and universities.

\section{REFERENCES}

[1] Fang Xuesen. The Positioning of the Teaching and Research Section of Local Applied Undergraduate Colleges [J]. Journal of Chizhou University. 2018(2):144. (in Chinese)

[2] Zhang Yulin, Liu Juan. Study on the Problems and Countermeasures of the Construction and Management of Teaching and Research Sections in Private Colleges and Universities [J]. China Educational Technology \& Equipment. 2018(12):17. (in Chinese)

[3] Tian Gang, Hu Xiaoqin. The System Construction of Teaching and Research Sections in China's Colleges and Universities Based on Comparison Between China and Foreign Countries [J]. Journal of Higher Education Finance. 2016(12):30. (in Chinese) 